\title{
Wartości patriotyczne w doświadczeniu polskich migrantów w Wielkiej Brytanii
}

Problematyka aksjologiczna odgrywa niezwykle ważną rolę w historii świata. Człowiek od początku szukał odpowiedzi na pytanie, co jest dobre dla niego, dla jego najbliższych czy dla większej społeczności. Nie były to tylko dywagacje filozoficzne, gdyż poszukiwanie dobra odnajdujemy także w innych artefaktach kulturowych, między innymi w literaturze czy sztuce. Termin „dobro” (łac. bonum) jest tu o tyle ważny, że przez stulecia właśnie nim posługiwano się, aby opisać to, co wartościowe i przez człowieka pożądane. W starożytności Arystoteles ukazywał dobro przez pryzmat celu, do którego dąży osoba ludzka. „Cele jednak bywają różne; jedne z nich bowiem są czynnościami, inne jakimiś odrębnymi od nich wytworami”. Z końcem XIX wieku termin „wartość” wszedł do słowników i stał się przedmiotem akademickich dyskusji jako określenie stosowane w analizach jednostkowych i społecznych. Nawet historię ludzkości można opisać przez pryzmat przemian wartości, a co więcej, można nawet zaryzykować stwierdzenie, że byłaby to niezwykle ciekawa lektura.

W naukach szczegółowych, do których zaliczamy między innymi psychologię, socjologię, ekonomię czy prawo, wartość oznacza termin wskazujący na to, co jest pożądane lub godne pożądania. Ma więc on swoje osobowościowe, społeczne czy kulturowe uwarunkowania, które również stają się przedmiotem badań naukowych. Dostrzec tu można subiektywistyczny charakter wartości, gdyż dla badaczy kluczowe jest ukazanie tego, co faktycznie uznawane jest przez jednostkę czy daną badaną zbiorowość za godne pożądania. Wartości są więc

\footnotetext{
Ks. dr Tomasz StanisŁaW Adamczy - Katedra Socjologii Kultury, Religii i Migracji WNS KUL, e-mail: xtomaszadamczyk@gmail.com, ORCID: 0000-0002-8288-5783.

1 Arystoteles, Etyka nikomachejska, tłum. D. Gromska, Warszawa 1982, s. 3.
} 
subiektywistycznymi zjawiskami społecznymi. Takie ich ujęcie nie jest jedyną koncepcją spotykaną w nauce. Niektórzy podkreślają niezależność wartości, zarówno od świadomości ludzkiej, jak i od subiektywnych ocen. Koncepcja ta ukazuje autonomiczność istnienia wartości i ich niezależność od jednostkowej aprobaty. Bez względu na spory naukowe związane z naturą wartości, warto podkreślić, że socjologowie ukazują w swoich pracach znaczenie wartości w życiu jednostek i grup społecznych oraz opisują różne wartości i systemy aksjologiczne $^{2}$. Wśród wielu definicji funkcjonujących w socjologii poniższe analizy będą się odwoływały do ujęcia wartości w rozumieniu Janusza Mariańskiego, który postrzega je jako „to wszystko, co wiąże się z pozytywnymi emocjami, co skupia na sobie pragnienia i dążenia jednostek i czego one jako «rzeczy» cennej poszukują na co dzień"3.

Od wielu lat podejmowane są również próby klasyfikacji i typologizacji wartości. Badacze dokonywali podziałów, które miały charakter zarówno naukowy, jak i nienaukowy. Uwzględniano przy tym kryteria, które były pochodną systemu religijnego lub filozoficznego. Inne typologie miały swoje źródło w kulturze lub w strukturze osoby ludzkiej, z rozróżnieniem na ciało, duszę i ducha. Stosowano również podział wartości ze względu na funkcje, jakie pełnią, a także podział na wartości deklarowane, wyznawane i praktykowane. Choć teoretycznie można by zakładać, że wartości nie powinny być rozróżniane, to jednak praktyka, zarówno życiowa, jak i badawcza, wskazuje na ich rozróżnienie ${ }^{4}$. W nauce istnieje wiele różnych podziałów wartości, których dystynkcje pozwalają na precyzyjniejsze i pełniejsze rozumienie postaw jednostkowych czy grupowych w badaniach socjologicznych.

W niniejszym opracowaniu zostaną opisane wartości patriotyczne, które należą do wartości podstawowych ze względu na swój uniwersalny charakter. Zalicza się do nich również godność osoby ludzkiej, prawa człowieka, solidarność, równość społeczną, wolność i życie. Warto zauważyć, że jedne $\mathrm{z}$ nich są akcentowane bardziej, a inne mniej, co jest uwarunkowane określonym kontekstem historycznym i społeczno-kulturowym. Wszystkie wartości podstawowe ukazują perspektywę realizacji dobra wspólnego ${ }^{5}$. Na początku polskiej transformacji Władysław Piwowarski patriotyzm wraz z religią i tolerancją uważał za wiodące wartości, które były ukształtowane w dłuższym

2 J. Mariański, Wartość/wartości, w: Leksykon socjologii moralności. Podstawy-teorie - badania - perspektywy, red. J. Mariański, Kraków 2015, s. 877-878.

3 J. Mariański, Socjologia moralności, Lublin 2006, s. 341.

${ }^{4}$ K. Żygulski, Klasyfikacja i typologia wartości, w: Socjologia wychowania. Wybór tekstów, red. H. Mielicka, Kielce 2000, s. 221-224.

5 W. Piwowarski, ABC katolickiej nauki społecznej. Cz. 1 (Wprowadzenie, podstawy, kierunki), Pelplin 1993, s. 76-77. 
czasie i uzyskując społeczną aprobatę, znalazły się wśród kluczowych wartości w życiu narodu polskiego ${ }^{6}$.

Liczne badania socjologiczne dowodziły, że patriotyzm pełnił niezwykle ważną rolę w polskim społeczeństwie. Był on czynnikiem integrującym Polaków w różnych momentach historii, a w hierarchii wartości społeczeństwa polskiego uzyskiwał wysoki wskaźnik jako jedna z kluczowych wartości. Samo słowo patriotyzm pochodzi z języka greckiego od patriotes - rodak, współobywatel, czy łacińskiego patria - ojczyzna. Jest on cnotą moralną miłości skierowanej do ojczyzny, jej dziedzictwa historycznego, kulturowego oraz ładu moralno-społecznego. Ma swój szczególny wyraz w gotowości ponoszenia na jej rzecz wszelkich ofiar. Według Encyklopedii Katolickiej patriotyzm jest „naturalną postawą zgodną ze społeczną naturą człowieka; oprócz wspólnoty podstawowej, czyli rodziny, najbardziej typową, trwałą, konieczną i wytwarzającą najsilniejsze zobowiązania wzajemne jest naród (gentes, nationes): przy czym presupozycja na rzecz ojczyzny i narodu nie jest ani arbitralna, ani nie wyklucza poszanowania i sympatii dla innych narodów, lecz wynika $\mathrm{z}$ naturalnego porządku miłości (odro caritatis), dającego pierwszeństwo temu, co najbliższe"” .

\section{Metodologia badań socjologicznych przeprowadzonych wśród polskich migrantów}

Badając patriotyzm z wykorzystaniem metod ilościowych i jakościowych, z perspektywy socjologicznej, należy dokonać dwóch procesów: konceptualizacji i operacjonalizacji. Pierwszy z nich, opisując rzecz lapidarnie, dotyczy tworzenia definicji pozwalającej zrozumieć omawiane zagadnienie. Drugi proces jest natomiast związany z poszukiwaniem konkretnych wskaźników pozwalających na empiryczną egzemplifikację badanego tematu. W środowiskach akademickich, zwłaszcza w naukach humanistycznych, przyjmowane są jednak różnorodne definicje. Sposób rozumienia patriotyzmu i możliwość jego badania w naukach socjologicznych to wiele ujęć, aspektów i elementów. W prowadzonych analizach ukazany on został poprzez następujące zagadnienia: dumę z bycia Polakiem, stosunek do swojego kraju oraz sposób podtrzymywania i rozwijania polskości na emigracji. Elementy te nie ukazują patriotyzmu w całej jego złożoności. Przeprowadzone badania socjologiczne nie były skoncentrowane na patriotyzmie, jednak uzyskany materiał empiryczny okazał się wystarczający dla opisu tej wartości w doświadczeniu polskich migrantów w Wielkiej Brytanii. Rozbudo-

6 W. Piwowarski, Podstawowe wartości społeczeństwa polskiego, w: Liberalizm i katolicyzm dzisiaj, Lublin 10-12 XI 1992, Warszawa 1994, s. 7.

7 J. Bartyzel, Patriotyzm, w: Encyklopedia Katolicka, red. F. Gryglewicz, t. 15, Lublin 2011, s. 51. 
wanie omawianego zagadnienia o dodatkowe możliwe wątki spowodowałoby konieczność znaczącego zwiększenia objętości tekstu

Badania socjologiczne z zastosowaną metodą badań jakościowych przeprowadzono w jednym z miast w Wielkiej Brytanii w 2015 roku. Wzięło w nim udział pięćdziesięciu trzech migrantów, wśród których było: 23 mężczyzn i 30 kobiet; 20 osób z wykształceniem wyższym, cztery - niepełnym wyższym, 25 - średnim, trzy z zawodowym i dwie z podstawowym. Warto podkreślić, że badani migranci przyjechali do Wielkiej Brytanii po wstąpieniu Polski do Unii Europejskiej. Rozmowy przeprowadzono techniką jakościowego wywiadu pogłębionego częściowo strukturalizowanego. Warto tu zauważyć, że badania jakościowe pozwalają na zdobycie pogłębionych informacji, a dane liczbowe nie odgrywają tu znaczącej roli, jak ma to miejsce w przypadku badań ilościowych. Cytowane poniżej stwierdzenia migrantów nie obejmują wszystkich ich wypowiedzi związanych z danym zagadnieniem. Umieszczono jedynie te, które mają charakter reprezentatywny dla omawianego w prowadzonych wywiadach wątku. Po zakończonej wypowiedzi umieszczony jest kod zawierający oznaczenie płci (K lub M) oraz numer cytowanej osoby. Czasem w tekście zawarte są również dodatkowe informacje o danym migrancie (wiek, wykonywany zawód, czas pobytu w Wielkiej Brytanii).

\section{Hierarchia wartości badanych respondentów}

Dla pełnego ukazania wartości patriotycznych w doświadczeniu migrantów ważna jest ich hierarchia aksjologiczna. W trakcie badania poproszono respondentów o wymienienie trzech najważniejszych dla nich wartości. Podobnie jak w wielu analizach socjologicznych przeprowadzanych metodą ilościową w Polsce najczęściej wskazywaną najistotniejszą wartością w życiu migrantów była rodzina. Na 53 rozmówców 41 wymieniło ją jako jedną z trzech najważniejszych wartości i w zdecydowanej większości ulokowało ją na pierwszym miejscu. Drugą najczęściej wymienianą wartością był Bóg/religia/wiara. Trzecią - zdrowie, wskazane przez 12 osób. W pierwszej trójce wskazywane były również: miłość (dziesięć osób), szacunek (pięć osób), szczerość (pięć osób). $\mathrm{Na}$ ojczyznę wskazały cztery badane osoby.

Kobieta od siedmiu lat przebywająca na emigracji w pytaniu o trzy najważniejsze wartości w jej życiu powiedziała: „Bóg, honor, ojczyzna. To jest moje” (K22). Podobnej odpowiedzi udzieliła kobieta przebywająca na emigracji od

8 Więcej informacji na temat charakteru badań, metodologii i różnych aspektów życia migrantów zawiera publikacja: J. Plewko, W. Szymczak, T. Adamczyk, Doświadczenie rozwoju w życiu polskich migrantów w Wielkiej Brytanii, Lublin 2018. 
pięciu lat: „Bóg, rodzina, ojczyzna” (K39). Następna rozmówczyni, również pracująca w Wielkiej Brytanii od pięciu lat, ujęła temat obrazowo: „Nigdy nie zapomnieć o tym właśnie, że jesteśmy Polakami przede wszystkim i pamiętać skąd. To jest śmieszne. Chcę spędzić życie tutaj, ale pochowana chciałabym być na tej ziemi, gdzie się urodziłam i gdzie jest reszta mojej rodziny, gdzie leży" (K40). Innymi wartościami wysoko cenionymi przez tę rozmówczynię były praca i rodzina. Jedynym mężczyzną, który wśród trzech najważniejszych wartości wymienił ojczyznę, był 44-latek: „Bóg, honor, ojczyzna, można powiedzieć. I to się wszystko zawiera w tym co mówię, bo np. ta ojczyzna to też rodzina. Honor to życie według jakiś zasad, żeby nie robić nikomu krzywdy, żeby postępować zgodnie z jakimiś tam wartościami, żeby człowiek przeżył to życie i żeby na koniec sobie uświadomił, że było wszystko dobrze" (M47) ${ }^{9}$.

\section{Duma z bycia Polakiem}

Opisując współczesne przemiany społeczne i kulturowe w dobie globalizacji, Edmund Wnuk-Lipiński wskazuje na zjawiska relatywizacji, fragmentaryzacji i detradycjonalizacji. Powodują one kryzys tożsamości jednostek i grup społecznych ${ }^{10}$. Kryzys ten dotyka zarówno zbiorowości o wysokim stopniu zurbanizowania, heterogenicznych kulturowo czy kosmopolitycznych, jak również małe lokalne środowiska. Edmund Wnuk-Lipiński zauważa, że identyfikacja ludzi i grup z państwem narodowym bywa często naruszana. Pojawiają się wówczas dwie alternatywne identyfikacje. Pierwsza $\mathrm{z}$ nich związana jest $\mathrm{z}$ postawą kosmopolityczną, a druga z przywiązaniem do małej ojczyzny ${ }^{11}$.

Współcześnie wzrasta liczba punktów odniesienia będących ważnymi elementami definiowania siebie i innych. Związane jest to ze zjawiskiem relatywizacji polegającej na porównywaniu siebie, grupy społecznej czy nawet całego społeczeństwa $\mathrm{z}$ innymi jednostkami, grupami czy społecznościami o odmiennych kulturach i wartościach. Zmiany w tożsamości w społeczeństwach zamkniętych dokonywały się zdecydowanie rzadziej. Transmisja wartości międzypokoleniowych nie była wówczas zakłócana przez czynniki zewnętrzne. Radykalne zmiany społeczne powodują zgoła odmienne uwarunkowania dla zmian tożsamościowych. Ma to miejsce choćby w przypadku migrantów

9 Socjologiczna analiza hierarchii wartości badanych migrantów została szerzej przeze mnie opisana w rozdziale Przemiany religijności migrantów we wspomnianej już publikacji Doświadczenie rozwoju w życiu polskich migrantów w Wielkiej Brytanii.

10 E. Wnuk-Lipiński, Świat międzyepoki, "globalizacja», «demokracja», "państwo narodowe», Kraków 2014, s. 226.

11 Tamże, s. 234-235. 
zmieniających nie tylko kraj zamieszkania, ale często i krąg cywilizacyjny ${ }^{12}$. Ukształtowana i stabilna tożsamość jednostek ulega zmianom, które dotykają również kwestii identyfikacji z narodem. Powstaje wówczas wspomniana tożsamość kosmopolityczna przyjmująca postać „obywatela świata” ${ }^{3}$.

Warto też zwrócić uwagę na inne okoliczności i uwarunkowania. Janusz Mariański, pisząc o patriotyzmie Polaków, zauważa: „W latach dziewięćdziesiątych $\mathrm{XX}$ wieku pojawiły się wprost ataki z różnych pozycji ideologicznych na wartości narodowe. Wartości te były pomijane, deprecjonowane, a nawet ośmieszane. Krytykowano nacjonalizm Polaków, ich przywiązanie nadmiernej wagi do własnej odrębności i symboliki narodowej. W więzi narodowej dostrzegano źródło nieufności, niechęci i wrogości wobec innych narodów. Postawy patriotyczne uznano za jedną z przeszkód w kontekście integracji europejskiej i ogólnoświatowej. Często przeciwstawiano tradycji narodowej tradycję uniwersalną, charakteryzującą się myśleniem o przyszłości w kategoriach europejskich, a nawet globalnych, lub przeciwstawiano orientację tradycyjno-narodową orientacji na modernizację"14. Kontekst społeczno-kulturalny niesprzyjający patriotyzmowi nie spowodował jednak znaczących zmian w postawach Polaków wobec swojego narodu. W Polsce w ostatnich latach XX wieku dostrzec można odradzanie się wartości patriotycznych oraz rewitalizację postaw narodowych. Potwierdzają to również różne badania socjologiczne. Dla przykładu można podać sondaż EVS z roku 2008, gdzie połowa Polaków w sposób zdecydowany identyfikowała się z narodem (50,4\%), blisko połowa wybrała odpowiedź „raczej tak” (45,5\%), a tylko co dwudziesty czwarty Polak nie deklarował takiej identyfikacji (raczej nie - 3,8\%; zdecydowanie nie - 0,4\%). Badania Europejskiego Systemu Wartości (EVS) wskazały również, że Polacy są w czołówce krajów europejskich objętych tymi sondażami ${ }^{15}$. W sondażu CBOS z roku 2016 zdecydowana większoóć Polaków uważała siebie za patriotów (zdecydowanie tak - 43\%, raczej tak - 45\%), natomiast co dziesiąty był zdania przeciwnego (raczej nie - 6\%, zdecydowanie nie $-3 \%$, trudno powiedzieć - 3\%). Wskaźniki częstotliwości dumy z bycia Polakiem były następujące: bardzo często - 38\%, dość często - 36\%, raczej rzadko $-21 \%$, praktycznie nigdy to się nie zdarza $-3 \%$, trudno powiedzieć $-2 \%^{16}$.

Analiza poszczególnych aspektów patriotyzmu w doświadczeniu migrantów rozpocznie się od zagadnienia dumy narodowej. Lapidarne stwierdzenie: „jestem

12 Tamże, s. 208-209.

13 Tamże, s. 219-227.

14 J. Mariański, Patriotyzm Polaków w świetle badań socjologicznych, w: Wychowanie dla Niepodległej. W setna rocznicę odzyskania przez Polskę Niepodległości, red. L. Pawelski, Szczecinek 2018, s. 35.

15 A. Jasińska-Kania, Dynamika zmian wartości Polaków na tle europejskim: EVS 1990-1999-2008, w: Polska po 20 latach wolności, red. M. Bucholc, S. Mandes, Warszawa 2011, s. 236-237.

16 R. Boguszewski, A. Głowacki, Miedzy patriotyzmem a nacjonalizmem, Komunikat z badań CBOS, 2016, nr 151, s. 1-5. 
dumny z bycia Polakiem" pokazuje pewną pozytywną identyfikację z polskim narodem. Samookreślenie się rozmówców w tej kwestii ma charakter subiektywny, a odpowiedź pozytywna: ,jestem dumny” nie oznacza automatycznie przyjęcia konkretnych patriotycznych postaw. Można hipotetycznie nawet założyć, że ktoś nie złoży takiej deklaracji, a w jego postawie będzie można odnaleźć zachowania wskazujące na patriotyzm. Deklaracja dumy z bycia Polakiem bądź jej brak pośrednio wskazują również na identyfikację (bądź jej brak) z pewnymi wartościami wyrastającymi z polskiej tradycji. W doświadczeniu migrantów może również oznaczać brak identyfikacji z innymi rodakami.

Uczestników badania w odniesieniu do pytania o dumę z bycia Polakiem można podzielić na trzy grupy. Pierwsza $\mathrm{z}$ nich jednoznacznie deklarowała swoją dumę w tym względzie, co ilustruje wypowiedź trzydziestotrzyletniego informatyka: „Bycie Polakiem to jest powód do dumy” (M1), czy trzydziestodziewięcioletniego taksówkarza, od jedenastu lat przebywającego na emigracji: „Tak, jestem dumny z tego, że jestem Polakiem. Gdy dużo klientów mnie pyta w taksówce, skąd jestem, zawsze odpowiadam, że jestem z Polski” (M19). $\mathrm{W}$ podobnym tonie wypowiadał się również trzydziestosześcioletni kierownik magazynu: „Mówię, że jestem Polakiem i nigdy się tego nie wstydziłem, mogę powiedzieć, że jestem z tego dumny, zawsze byłem i będę Polakiem" (M31). Trzydziestosiedmioletni menadżer w firmie informatycznej, oprócz poczucia dumy narodowej, dostrzega pewne mankamenty w postawach swoich rodaków: „Tak. Ja jestem dumny. Nie jestem dumny ze wszystkiego, co Polacy robią, ale nie odpowiadam za wszystkich. Ja nigdy nie ukrywałem tego, że jestem Polakiem". Również kobiety, które wzięły udział w badaniach socjologicznych, podkreślały dumę z przynależności narodowej. Za przykład niech posłuży wypowiedź pracowniczki magazynu: „Nigdy tego się nie będę wstydziła i ukrywała tego, kim jestem" (K40) czy księgowej, która pytana o dumę z bycia Polką, odpowiada: „Bardzo. I zawsze podkreślam moim dzieciom, że one mają być dumne, że są Polakami i nigdy w życiu się mają tego nie wstydzić. Nawet w szkole będąc one zawsze podkreślają, że są Polakami” (K11). Kolejna rozmówczyni, sześćdziesięcioletnia kobieta pracująca $\mathrm{w}$ restauracji, powiązała polskość $\mathrm{z}$ katolicyzmem i swoją małą ojczyzną, czyli miejscem swojego pochodzenia: „Ja jestem Polką od urodzenia. To jest bardzo dużo. Ja zawsze każdemu mówię, że jestem dumna z tego, że jestem katoliczką, Polką, ze wsi pochodzę i na wieś wracam. To jest moje motto" (K22).

Niektórzy z respondentów podawali uzasadnienie powodów swojej dumy narodowej. Mężczyzna, z wykształcenia archeolog, mówił: „Jesteśmy inteligentnym narodem i sobie radzimy wszędzie" (M32). Dwudziestosześcioletnia kobieta zwracała uwagę na polską tradycję: „Podoba mi się nasze życie, nasze zwyczaje. Jestem zadowolona z tego. Pewnie jak bym się urodziła Brytyjką, to pewnie też byłabym zadowolona $\mathrm{z}$ tego" (K6). Warto tu zauważyć, że ceni 
polską tradycję dlatego, że stała się jej częścią poprzez wzrastanie w niej, a nie ze względu na jej wartość samą w sobie. Trzydziestoośmioletni mężczyzna pracujący jako elektryk zwrócił uwagę na przywiązanie do języka ojczystego: „Nawet w mojej firmie przechodzę i oni mówią: [...] mów tutaj po angielsku. Mówię: nie, ja jestem tutaj Polakiem, będę mówił po polsku, to wy się nauczcie polskiego" (M10). Kobieta od ponad dziesięciu lat przebywająca wraz z mężem na emigracji, stwierdziła: „Jak najbardziej. Ani się tego nie wstydzę. Nie mam powodu do tego. Ja nic nie zrobiłam, nie jestem złodziejem, nie jestem złym człowiekiem. Ja tu ciężko na to wszystko pracuję i płacę podatki, także nie mam powodu do wstydu" (K28). Trzydziestotrzyletni informatyk, podkreślając, że polskość do powód do dumy, dodał: „Ale czy aż tak się emanujemy tym, że jesteśmy Polakami? Wydaje mi się, że nie. [Czyli ta duma z polskości nie ma konkretnych przejawów? - T.A.] Nie chwalimy się tym. Na ulicy ciężko byłoby powiedzieć, znaczy czy to są Polacy, czy nie-Polacy, ale to nie jest sposób, w jaki tu się ludzie zachowują" (M1). Respondent pracujący jako taksówkarz zwracał uwagę na opinię o Polakach w Wielkiej Brytanii: „Polacy tutaj w ogóle mają dobrą opinię jako dobrzy ludzie, pracowici, uczciwi, religijni, także jestem dumny z tego, że jestem Polakiem” (M19). Dodał również: „Polska jest dalej moim krajem. Ja jestem Polakiem, czuję się Polakiem, chętnie wracam do Polski. [...] Ale teraz z perspektywy 11 lat życia tutaj na emigracji zaczynam się bardziej czuć Europejczykiem" (M19). Inną okazją do wyrażania dumy z bycia Polakiem są wydarzenia sportowe i manifestowanie przy okazji uczestnictwa w nich przywiązania do barw narodowych. Te elementy znalazły się w wypowiedzi czterdziestoczteroletniego mężczyzny pracującego jako malarz: „Nawet jak oglądam mecze, tutaj jest olimpiada czy coś, to z synem oglądamy. Nawet się przebieramy, stroje polskie mamy. [...] w szaliku. I na meczu też byliśmy, jak Irlandia - Polska grała" (M14).

Drugą grupę stanowili rozmówcy, którzy w reakcji na pytanie o dumę z bycia Polakiem zachowywali pewien dystans. Do tej grupy należy kobieta z wyższym wykształceniem, pracująca w dystrybucji handlowej: „Czy jestem dumna? Nie wstydzę się tego, o tak powiem. Trudno mi mówić, czy jestem dumna, ale nie wstydzę się tego, nie ukrywam tego w żaden sposób. Nie obnoszę się też z tym. Myślę, że, nie wiem, czy jestem dumna. Ale na pewno się tego nie wstydzę. Myślę, że dumna to tak za dużo powiedziane" (K3). W dalszej rozmowie jeszcze raz okazała pewną rezerwę do patriotyzmu, ściślej do jednego jego elementu tęsknoty za rodzinnym krajem: „Nie jestem jakąś szczególną patriotką chyba raczej. Z tego, co tu powiedziałam, raczej chyba tak wynika. Żyje mi się tutaj dobrze i nie mogę narzekać. Nie mogę powiedzieć, że wrócę, bo bardzo tęsknię za Polską, czy czuję się bardzo mocno patriotką, bo to nie byłaby prawda" (K3). Pewną rezerwę do poczucia dumy narodowej ilustruje także wypowiedź kobiety pracującej jako designer: „Nie wiem. To pewnie wiele czynników wpływa, że 
może jestem dumna, ale też może nie ma powodów do dumy" (K9). W dalszej części wyjaśniła, że wolałaby żyć w Polsce, a nie w Wielkiej Brytania na emigracji: „To jest jeden powód, dla którego nie jestem dumna. Kraj powinien zrobić tak, żeby trzymać nas w kupie, dać szansę, ale nie za tym podstawowym chlebem. A czy jestem dumna? Pewnie tak. Nie jestem jakąś taką silną patriotką" (K9). Rozmówczyni ta została zaliczona do tej grupy ze względu na sprzeczność wypowiedzi - stwierdzenia, że zarówno jest, jak i nie jest dumna. Pewien dystans do pytania dotyczącego dumy z bycia Polakiem zachował również trzydziestoletni mężczyzna: „Nie wiem, czy jestem dumny. [...] Czy to jest w ogóle jakaś kategoria?” Dalej wyjaśniał: „Bo Anglik jest dumny, że jest Anglikiem, Szkot jest dumny, że jest Szkotem, Nigeryjczyk pewnie jest dumny, że jest Nigeryjczykiem, chociaż woli być pewnie Brytyjczykiem". Po dopytaniu rozmówca doprecyzował, że narodowość nie jest kwestią wyboru: „Ale nawet jeżeli ktoś nie ma wyboru, to myślę sobie, że czy ma wybór, czy nie ma wyboru, to właściwie nie ma znaczenia. Bo mogę powiedzieć, że «nie jestem dumny z tego, że jestem Polakiem». Ale jak nie mam wyjścia, to co mogę zrobić, przecież nie strzelę sobie w łeb z tego powodu" (M32).

Ostatnią grupę stanowili respondenci, którzy na pytanie o dumę z powodu bycia Polakiem odpowiadali jednoznacznie negatywnie. Dwudziestosiedmioletnia kobieta pracująca w firmie komputerowej wprost stwierdziła: „Nie, nie jestem dumna" (K26). Jako jeden z powodów wskazała na sytuację w kraju: „Może te stereotypy, które ludzie jednak przekazują sobie, może też to, jak w tej naszej Polsce jest". Wskazała również na postawy Polaków na emigracji: „Pracuje się z nami bardzo źle, że ludzie mówią, że nie chç̨ z nami pracować, oczywiście to nie mówią obcokrajowcy, tylko to my sami o sobie mówimy, czyli jeżeli np. tutaj sytuacja polityczna jest taka, że oni po prostu nas już tutaj nie chcą". W dalszej części swojej wypowiedzi dostrzegła zróżnicowanie Polaków: „Nie jesteśmy wszyscy tacy sami i nie każdy postępuje tak, jak dany stereotyp mówi, ale właśnie krąży dużo takich nieprzyjemnych opinii”. Zwróciła również uwagę na problem braku współpracy pomiędzy migrantami: „Nie potrafimy się ze sobą dogadać nawet na doświadczeniach z ośrodka tutaj. Jest taki bardzo podzielony, że szkoła, kościół, jakieś tam inne ugrupowania, kościół rodzinny, Kościół Domowy, jakiś tam jeszcze inny, jest to jeden wspólny ośrodek, więc zamiast go jakoś budować, podnosić, żeby wszystko to funkcjonowało sprawnie, razem, to oni próbują to wszystko każdy na swoją stronę" (K26). Warto zauważyć, że niektórzy migranci zwracali uwagę na Polaków, którzy ukrywają swoją narodowość. Za ilustrację takich postaw może posłużyć wypowiedź mężczyzny pracującego w handlu: „Wiem, że jest tu dużo osób, które może się wstydzić, że jest Polakami, co mi się nie podoba np. czasami ludzie próbują, spotkałem się z tym wielokrotnie, że ludzie próbują udawać kogoś innego niż są, np. mówią po angielsku do dzieci jak są w towarzystwie angielskim, a za chwilę mówią po 
polsku” (M33). Dodał jeszcze, że niektórzy migranci wstydzą się swojej polskości: „Myślę, że niektórzy tej polskości się wstydzą, a ja jakoś nigdy nie miałem z tym problemu i ktokolwiek mnie poznaje, to mówię, że jestem Polakiem i nigdy się tego nie wstydziłem, mogę powiedzieć, że jestem z tego dumny, zawsze byłem i będę Polakiem" (M33).

\section{Stosunek do kraju ojczystego}

Zderzenie ze społeczeństwem wielokulturowym, w którym spotyka się różne, często odmienne systemy wartości, sprzyja rozmaitym porównaniom. $Z$ początku dostrzega się różnice i wszelkie odmienności, wyrywające z rutyny i przyzwyczajeń w postrzeganiu rzeczywistości. Pobyt na emigracji pozwala również nabrać dystansu do tego, co polskie i w Polsce. Powyższe uwarunkowania mogą sprzyjać także zmianom w nastawieniu do kraju ojczystego. Również o tę kwestię zapytano migrantów uczestniczących w badaniu socjologicznym. Ich wypowiedzi można podzielić na trzy grupy. Pierwsza grupa to osoby, które na emigracji zmieniły swój stosunek do ojczyzny w kierunku pozytywnym. Przykładem jest czterdziestoletni mężczyzna wyjeżdżający z kraju z awersją: „Jak wyjechałem, było negatywnie, strasznie negatywnie. [...] Z czasem już tak przechodzi. Człowiek jest tylko człowiekiem" (M14). Na emigracji postrzega swój kraj w odmienny sposób, podkreślając szczególnie możliwość powrotów: „Pozytywne w Polsce jest to, że się w Polsce jest przede wszystkim. To jest najważniejsza rzecz. Bo wszędzie jest dobrze, ale w domu jest najlepiej, jak to każdy powtarza. Naprawdę. I moim zdaniem chyba nie ma ładniejszego kraju niż Polska jest" (M14). Trzydziestotrzyletnia kobieta podkreślając, że z dystansu lepiej pewne kwestie dostrzec w kraju, dodaje: „Postrzegam Polskę jeszcze jako miejsce w Europie, w którym jeszcze jest nadzieja na to, aby chronić te podstawowe wartości człowieka, w którym jeszcze nie ma tzw. tolerancji na to całe zło, co tutaj jest normalne, [...] Polska jeszcze jest tym krajem w tej Europie, że jeszcze jest tam ziarno nadziei na to, że cokolwiek da się odratować i będąc tam jeszcze się czuje to, że ludzie inaczej postrzegają takie rzeczy, które tutaj są na porządku dziennym" (K13). Negatywnie postrzega ona rozszerzoną ustawę pozwalającą w Wielkiej Brytanii na aborcję, a także zgodę na zawieranie związków małżeńskich przez pary homoseksualne. Inny rozmówca mówi o zmianach, które nastąpiły w Polsce: „Wydaje mi się, że jest lepiej. [...] Nie mogę nic zbytnio powiedzieć, bo ja tam nie pracuję, nie mieszkam. A jeżeli przyjeżdżam, jadę nawet do swojej miejscowości, wygląda to całkiem inaczej, wygląda to lepiej. Wszyscy mają dość fajne samochody [...]. Wydaje mi się, że podwyższył się poziom życia" (M36). Podobnie wypowiada się dwudziestodziewięcioletni mężczyzna pracujący jako magazynier: „Po dziesięciu latach na pewno widzę, 
jak się Polska zmienia, że powstają nowe, ładne domy. Widać, bo to się zmienia. Nie jest się tam cały czas. Po rodzinie widzę, po swoich braciach" (M52).

Druga grupa rozmówców to emigranci, którzy zmienili swój stosunek do kraju na negatywny. Ilustruje to wypowiedź kobiety będącej technikiem farmacji: „Przekonałam się, że poza krajem też można żyć dobrze i godnie, a wcale nie gorzej, a wręcz przeciwnie, nawet lepiej, więc to chyba tylko tyle" (K8). W dalszej części rozmowy podkreśliła, że w Wielkiej Brytanii żyje się prościej i łatwiej. Swój żal do kraju wyraża również mężczyzna pracujący jako monter, uzasadniając to względami ekonomicznymi: „To powiem, że cieszę się, że przyjechałem tutaj. Żal ściska, bo źle jest, żeby Polak z kraju wyjeżdżał za pracą" (M5). Z kolei na opinii trzydziestosiedmioletniej pielęgniarki zaważyły różnice w relacjach międzyludzkich na obczyźnie i w kraju: „Polacy są takim narodem, gdzie jedni patrzą na drugich, bo co ludzie powiedzą itd. Tutaj tego nie ma i tak sobie tutaj dopiero uświadomiliśmy, że bez sensu ten stres w Polsce, bo co ludzie powiedzą, bo trzeba robić, bo tak wypada, to zupełnie bez sensu i my tak staramy się naszym rodzicom, żeby zwolnili, żeby tak żyjcie dla siebie, nie martwcie się o ludzi, ale to jest trudno właśnie takiego dystansu nabrać” (K16). $\mathrm{W}$ podobnym tonie wypowiada się trzydziestotrzyletnia kobieta: „Zmieniło mi się. To jest śmieszne, ale bardziej na negatywny zmieniłam. Stwierdziłam, że ludzie w Polsce są bardzo zacofani” (K43). Dalej swój negatywny stosunek do Polaków uzasadniła brakiem otwartości.

W ostatniej grupie znaleźli się respondenci, których stosunek do Polski nie zmienił się na emigracji. Są tu osoby prezentujące zarówno negatywny stosunek do kraju, jak i pozytywny. Przykładem pierwszej postawy są wypowiedzi mężczyzny przebywającego na emigracji od trzech lat: „Myślę, że mój stosunek do Polski jest taki sam, jak był, jak byłem w Polsce, jak mieszkałem w Polsce. Szczerze mówiąc, chciałbym wrócić, ale tak jak Panu powiedziałem, tylko i wyłącznie, jak się coś zmieni w Polsce. Na pewno nie w tym momencie, na pewno nie w najbliższych pięciu latach" (M10). Jednak rozmówca ten wspomina również, że wielokrotnie był już blisko podjęcia decyzji o powrocie do kraju, bo: „Nic poza tym dobrego nie daje emigracja. Co daje? Nic nie daje. Spotykasz się tutaj z Polakami czy z Anglikami i to wszystko [...]. Szczerze mówiąc to jest takie ciche umieranie tutaj, poważnie. Szczerze mówiąc, ja się nie potrafię tu rozwinąć, bo mnie przytłaczają te domy, ten zapach [...]. Wszędzie, niech pan spojrzy, tu są wszędzie cegły. To jest przytłaczające. [...] Tutaj się nie ma czym cieszyć" (M10). Wypowiedzi cytowanego rozmówcy naznaczone są dużą dawką negatywnych emocji, i to zarówno do swojego kraju, jak i do Anglii oraz do emigracji. O braku zasadniczej zmiany w postrzeganiu Polski z perspektywy migranta mówiła dwudziestopięcioletnia kobieta: "Jedynie to, że przerażają mnie twarze ludzi, jak jestem na wakacjach, dlatego, że są smutni, gdzie tego wcześniej nie widziałam, a będąc tutaj po dłuższym czasie nieobecności przy- 
jeżdzam i ja patrzę się, np. na zakupach jestem, to jest takie zwykłe, zwyczajne, zakupy, wszyscy ludzie chodzą wiecznie smutni i to mnie przeraża. To jest jedyna rzecz, która mnie przeraża - twarze i taki smutek w oczach" (K6). Elementy pozytywne dla odmiany dostrzec można w wypowiedzi kobiety zatrudnionej w magazynie: „Ciężko powiedzieć. Nie, nie sądzę. Jednak człowieka ciągnie, to jest coś, czego się chyba nie zapomina i nie da się tego pozbyć. To się ma w sobie i koniec. Jestem Polakiem i nic tego nie zmieni” (K25).

\section{Podtrzymywanie polskości na emigracji}

W przeprowadzanych wywiadach poruszano także kwestię związaną z podtrzymywaniem i rozwijaniem polskości na emigracji. Okazuje się, że wciąż ważną rolę w tym zakresie odgrywają różne instytucje, do których można zaliczyć kluby polskie, szkoły i parafie. Wspomagają one rodziny i pomagają zachowywać migrantom ich narodową tożsamość.

Badani rozmówcy najczęściej wskazywali na kwestie związane z używaniem języka polskiego jako sposobem podtrzymania polskości w Wielkiej Brytanii. Przykładem jest wypowiedź trzydziestosiedmioletniego stolarza: „W domu rozmawiamy po polsku z żoną. Chcemy, żeby nasza córka umiała mówić po polsku" (M4). Kolejny rozmówca, czterdziestotrzyletni monter, wskazując na rolę języka w podtrzymywaniu polskości, wspomina o rodakach wstydzących się mowy ojczystej: „Niektórzy to się wypierają, bo na samym początku jak pracowałem na warsztacie, już nie wspomnę o tych Polakach, co chodzą po ulicy i po angielsku gadają i mówią, że oni się czują bardziej Anglikami niż Polakami, a zachowanie mają takie, jakie mają" (M5). W podobnym tonie wypowiadała się trzydziestoośmioletnia kobieta pracująca w handlu. Podkreślając, że polskość pełni najwyższą rolę w jej życiu, dodała: „Głównie chodzi o zachowanie języka, dlatego, że ja widzę dzieci, które są już tutaj prawie urodzone, albo które przyjechały, ludzie zapominają i nie chcą rozmawiać po polsku" (K2). Trzydziestodwuletnia kobieta $\mathrm{z}$ wykształceniem wyższym podkreśliła szczególną rolę rodziny w nauce języka: „Uczymy dzieci polskiego. Nie pozwolę, żeby dzieci nie mówiły po polsku. Uczymy ich czytać, pisać obydwoje. Małego też już uczymy. Chcę, żeby dzieci znały nasz ojczysty język. Bo ja sobie nie wyobrażam, wielu ludzi nie uczy dzieci polskiego" (K8).

Bardzo ważną instytucją pozwalającą na podtrzymywanie i rozwijanie polskości jest szkoła. Wokół niej gromadzą się migranci, a jej oddziaływanie w omawianym aspekcie nie dotyczy tylko dzieci. Ich rodzice nawiązują kontakty $\mathrm{z}$ innymi migrantami, organizowane są różne akademie, spotkania i odczyty, które w znaczący sposób podtrzymują i rozwijają polskość w warunkach emigracyjnych. Jadwiga Plewko, opisując życie rodzinne migrantów na podstawie 
tych samych badań socjologicznych, zauważa że: „Szkoła sobotnia jest uzupełnieniem procesu socjalizacji w duchu polskości, realizowanego $\mathrm{w}$ rodzinach wielu migrantów, i stanowi przeciwwagę wobec wpływów języka angielskiego i brytyjskiego systemu edukacji, z którego dzieci w pełni korzystają "17. Ilustracją tego jest wypowiedź trzydziestoletniej kobiety mówiącej o sobotniej szkole: „Tu się pracuje przez cały tydzień. I festyny rodzinne są organizowane, [...] gdzie mogą się wszyscy spotkać, zintegrować. Dla dzieci są organizowane zabawy. Jest organizowane Święto Niepodległości zawsze, gdzie jest poczet sztandarowy i te wszystkie nasze przedstawienia, uroczystości, żeby tym dzieciom pokazać tą historię" (K40). Na rolę szkoły, ale także parafii, w kultywowaniu polskości wskazuje również kolejna wypowiedź: „Nasza szkoła, nasz dom parafialny, nasza parafia często organizuje różnego rodzaju spotkania, grille, festyny, zawsze w nich uczestniczymy" (M19). Migranci, którzy są rodzicami, często podkreślają rolę szkoły sobotniej w opanowaniu przez ich dzieci języka ojczystego, miewają jednak dylematy dotyczące priorytetów związanych z językiem angielskim i polskim. „Nasza córka chodzi do polskiej szkoły, ona jest w tej chwili na takim etapie, ona jest tym zachwycona i cała ta polska kultura i to wszystko, to jest świetne i piękne, natomiast ja zaczynam się w tym momencie martwić, bo ona jest na etapie, że zaczyna czytać. Jednak czytanie po angielsku i po polsku się różni i ja chciałabym, żeby ona najpierw opanowała ten pisany angielski, bo to jest priorytet, bo to jest jej główna szkoła" (K16). Zdarza się również, że nośnikiem polskości jest dalsze środowisko. Jeden z rozmówców opowiadał o koledze syna, chłopcu polskiego pochodzenia, którego uczy języka polskiego: „Jest Polak, który mieszka w Anglii chyba też 12 lat i nie mówi po polsku. Przychodzi do nas do domu i go po polsku uczymy. A rodzice są Polacy i go nie nauczyli w domu, czy nie chcieli, to już jest ich sprawa. I go tak uczymy po polsku tych słów" (M14).

Kolejnym sposobem podtrzymywania polskości jest wierność polskim tradycjom i zwyczajom. Ilustracją takiej postawy jest wypowiedź kobiety z wykształceniem wyższym: „Dla mnie tutaj tradycja i ten żurek, ten bigos na święta i to wszystko, tradycja kulturalna, tradycja polska i język polski u mnie w domu zawsze będzie i musi być. To jest bardzo ważne dla mnie dlatego, że ja wiem, że tylko ja mogę dzieciom to zaoferować, one tego w angielskich szkołach nie będą wiedziały, o co chodzi w ogóle. A mi byłoby wstyd bardzo, jakby moje dzieci nie wiedziały, skąd pochodzą" (K2). Podobnie polskość z tradycją łączy trzydziestosześcioletni kierownik magazynu: „Jeżeli chodzi o jedzenie czy o święta, staramy się cały czas, że tak powiem, żyć po polsku. Tradycje, święta różnego rodzaju czy Boże Narodzenie, czy Wielkanoc, czy różne religijne, staramy się

17 J. Plewko, Jakość życia rodzinnego, w: Doświadczenie rozwoju w życiu polskich migrantów w Wielkiej Brytanii, s. 105. 
obchodzić po polsku" (M31). W warunkach emigracyjnych wiele kwestii bywa na nowo odkrytych albo na nowo dowartościowanych. Potwierdza to wypowiedź trzydziestoletniej kobiety z wykształceniem wyższym: „Po wyjeździe zdałam sobie sprawę, jak wielu rzeczy nie doceniałam, będąc w Polsce. To są prozaiczne sprawy typu przestrzeganie różnych tradycji świątecznych na przykład [...] mam nadzieję, że nasze tradycje, wartości, kultura są bardzo ciekawe też dla innych osób" (K21). Także w przypadku przekazywania polskiej tradycji ważną rolę pełni szkoła, co podkreślała dwudziestopięcioletnia kobieta $\mathrm{z}$ wykształceniem średnim: „Po to jest właśnie polska szkoła, żeby uczyć od najmłodszego, nie zapominać o naszych tradycjach, o naszych zwyczajach i właśnie tym wszystkim, co się dzieje" (K6).

W warunkach emigracyjnych duże znaczenie w podtrzymywaniu polskości pełnią środki społecznej komunikacji. To często powtarzający się element $\mathrm{w}$ wypowiedziach respondentów. Pojawił się w rozmowie z trzydziestodziewięcioletnim mężczyzną: „Oglądamy polskie media, słuchamy polskich mediów, czytamy polskie portale” (M19). Podobnie wypowiadał się trzydziestosiedmioletni kontroler jakości: „Słuchaliśmy telewizji polskiej. Radia słuchaliśmy polskiego. Dzieci miały kontakt z Polakami przez internet, telefony" (M37). Rolę mediów podkreśliła również kobieta pracująca jako księgowa: „Dużo daje telewizja polska [...] myślę, że jestem bardziej polska w tej Anglii niż... znaczy źle powiedziałam, że dużo tej polskości jest, bardzo dużo" (K11). Na znaczenie mediów wskazała także kobieta zaangażowana w Harcerstwo Polskie: „Koledzy, koleżanki to sami Anglicy dookoła, są uczeni, żeby po polsku mówić. Mamy polską telewizję, więc jakoś tak tą polszczyznę trzeba utrzymać w tej rodzinie" (K23). Trzydziestoczteroletni mężczyzna z wykształceniem wyższym wykorzystuje zainteresowania sportowe, by uświadamiać swoim córkom ich korzenie: „Oglądając mecze piłki nożnej, zaczepić dziewczyny, córki, zaciągnąć przed telewizor i im tłumaczyć, że tu gra Polska, tutaj pan jest taki i taki, jak strzelimy gola, cieszymy się" (M45).

Migranci wskazywali również na inne sposoby podtrzymywania polskości. Jednym z nich jest korzystanie z polskich bibliotek: „Tu naprawdę mamy fajnie i nie powinniśmy marudzić. Są polskie szkoły. Są polskie książki w bibliotekach. O właśnie, korzystamy z biblioteki, uwielbiam chodzić do biblioteki, więc to jest jakiś tam element tutejszej kultury czy takiego lokalnego życia, bo w bibliotekach się dzieje, ale są polskie książki w bibliotece. Tu naprawdę się da" (K15). $\mathrm{Na}$ czytelnictwo polskich książek zwróciła uwagę również kobieta pracująca jako magazynier: „My sobie zawsze przywozimy książki z Polski. Oglądamy filmy po polsku, staramy się. Tutaj jest zupełnie inaczej, nie ma dostępu do wszystkiego" (K6). Były także osoby, które dostrzegały niewystarczającą troskę o rozwój swojej polskości. Trzydziestosiedmioletnia pielęgniarka widziała możliwości większego zaangażowania w tym względzie: „Bo tak jak mówię, okazje 
ku temu są, bo jest ta Polonia, która działa" (K16). Natomiast kobieta pracująca jako sprzątaczka dostrzegła możliwość rozwoju w podjęciu studiów na polskiej uczelni: „Ja chciałam nawet zacząć studia przez internet. Ale stwierdziłam, że ja nie mam na to czasu, bo ja mam tutaj szkołę i mam pracę, mam siłownię, i ja już bym nie miała na to czasu, żeby studiować przez internet. Bo jak bym wróciła do tej Polski, to siłą rzeczy chciałabym mieć tam jakieś studia zrobione, ale musiałabym chyba roczny bilet na Ryanaira sobie wykupić" (K12). Pracująca $\mathrm{w}$ fabryce trzydziestoośmioletnia kobieta wskazała na relacje rodzinne i religię jako elementy podtrzymujące i rozwijające polskość: „My utrzymujemy, tak jak mówiłam wcześniej, utrzymujemy tę polskość w domu. Jest polski kościół” (K23). Pracująca kobieta wskazuje również na wiarę jako czynnik podtrzymujący polskość, dodając również element związany z edukacją historyczną: „Moja mama była nauczycielką i ona od małego nas uczyła, co to patriotyzm, co to wiara, to było nieodłącznym elementem naszego życia. To samo, moje dzieci są bardzo wierzące i nawet mimo to, że są tutaj w Anglii, one wiedzą o fladze wszystko, o godle, nawet elementy historyczne, nawet książka tu jest dla dzieci «Historia Polski», także bardzo ważną rolę" (K11). Na te same elementy zwróciła uwagę także dwudziestotrzyletnia pracowniczka socjalna: „Od niedawna tak naprawdę zaczęłam się interesować tym, co się dzieje w Polsce. Niby znałam tę historię, bo zdawałam na maturze historię, chciałam iść na prawo, ale się nie dostałam, także ta historia gdzieś tam się przewijała w moim życiu, ale tak na poważnie się nie zastawiałam w ogóle nad polskością, ale dzięki temu, że tak jak wcześniej powiedziałam, pogłębiła się u mnie wiara i przez pryzmat wiary zaczęłam patrzeć na każdą sferę życia, nawet na politykę i to mi ułatwiło" (K13).

\section{Zakończenie}

W 2017 roku Rada ds. Społecznych działająca przy Konferencji Episkopatu Polski opracowała dokument zatytułowany Chrześcijański kształt patriotyzmu. Autorzy tekstu na początku zauważają ożywienie współczesnych postaw patriotycznych i oceniają je pozytywnie. Dodają również: „Miłość ojczyzny, umiłowanie rodzimej kultury i tradycji nie dotyczy bowiem wyłącznie przeszłości, ale ściśle się wiąże z naszą dzisiejszą zdolnością do ofiarnego i solidarnego budowania wspólnego dobra. Realnie zatem wpływa na kształt naszej przyszłości"18. Piszą także o postawach sprzeciwiających się patriotyzmowi, których kluczowym elementem jest egoizm: „Może to być egoizm indywidualny, obojętność na los wspólnoty narodowej, wyłączna troska o byt swój i swoich najbliższych. Takie ignorowanie bogactwa, które każdy z nas otrzymał wraz z wspólnym ję-

18 Konferencja Episkopatu Polski, Chrześcijański kształt patriotyzmu, Tarnów 2017, s. 3. 
zykiem, rodzimą historią i kulturą, połączone z obojętnością na losy rodaków, jest postawą niechrześcijańską. Jest nią także egoizm narodowy, nacjonalizm, kultywujący poczucie własnej wyższości, zamykający się na inne wspólnoty narodowe oraz na wspólnotę ogólnoludzką. Patriotyzm bowiem zawsze musi być postawą otwartą"19. Patriotyzm, który często bywa ukazywany jako miłość ojczyzny, przybiera różne formy, a jego karykaturą jest patos bez etosu. Przed laty Gustaw Herling-Grudziński w wymianie listów z abp. Józefem Życińskim poetycko napisał o cichej cnocie patriotyzmu ${ }^{20}$. Jej wyrazem jest postawa obywatelska, na którą składają się m.in.: życzliwość do innych ludzi, płacenie podatków, uczestnictwo w wyborach demokratycznych czy uczciwie i rzetelne wykonywanie swoich obowiązków rodzinnych i zawodowych.

Przeprowadzona analiza badań jakościowych zrealizowanych wśród polskich migrantów w Wielkiej Brytanii dotyczyła wartości patriotycznych. Niektóre aspekty zostały już pośrednio opisane przez Jadwigę Plewko i Wiolettę Szymczak w publikacji pt. Doświadczenie rozwoju w życiu polskich migrantów w Wielkiej Brytani $i^{21}$. Jednym z przejawów postawy patriotycznej może być udział w organizacjach non-profit, co jest wyrazem troski o innych. Wioletta Szymczak zauważa jednak, że badani migranci nie traktowali działań, które wykraczały poza zobowiązania rodzinne i przyjacielskie jako priorytetowych w kontekście swojego rozwoju. A przecież partycypacja społeczna: „Daje badanym poczucie przynależności, oparcia w sytuacjach trudnych czy kryzysowych, skutkuje budowaniem więzi oraz praktyką ich podtrzymywania"22. Na potrzeby opracowania dotyczącego wartości w doświadczeniu polskich migrantów uwaga badaczy została zogniskowana na wybranych elementach składających się na patriotyzm: poczucie dumy z bycia Polakiem, stosunek migrantów do kraju ojczystego oraz sposoby podtrzymywania i rozwijania polskości.

Duma z przynależności narodowej może zakładać afirmację wartości patriotycznych. Powody takiej postawy mogą być różne. Często związane są m.in. z historią narodu, religią, tradycją i kulturą czy doświadczeniem osobistym. Jednak brak dumy nie w każdym przypadku musi oznaczać brak patriotyzmu. Badania sondażowe przeprowadzone przez CBOS ukazały, że skłonność do odczuwania dumy związana jest $\mathrm{z}$ dwoma komponentami. Pierwszy $\mathrm{z}$ nich dotyczy ogólnej satysfakcji życiowej i charakterystyczny jest dla osób z odpowiednim statusem społecznym, stanem posiadania czy miejscem zamieszkania. Drugi komponent to światopogląd tradycjonalistyczny, który często jest reprezentowany przez

19 Tamże, s. 3.

20 G. Herling-Grudziński, J. Życiński, Pięć dialogów, Warszawa 1999, s. 47.

21 J. Plewko, W. Szymczak, T. Adamczyk, Doświadczenie rozwoju w życiu polskich migrantów $w$ Wielkiej Brytanii, Lublin 2018.

22 W. Szymczak, Obszary społecznej partycypacji absencji, w: Doświadczenie rozwoju w życiu polskich migrantów w Wielkiej Brytanii, s. 194. 
osoby starsze i emerytów, ludzi głęboko wierzących czy prezentujących poglądy prawicowe. Natomiast wstyd z powodu bycia Polakiem charakterystyczny jest dla młodych mieszkańców miast i osób pracujących na własny rachunek ${ }^{23}$. Badania jakościowe przeprowadzone w Wielkiej Brytanii pozwoliły wyłonić jeszcze trzecią kategorię Polaków. Oprócz migrantów dumnych z narodowości polskiej i tych deklarujących brak dumy są również tacy którzy umiejscawiają się „pomiędzy” tymi dwoma odczuciami. U części z nich występowała jednocześnie duma i brak dumy, a niektórzy wykazywali pewien dystans, zarówno do odczucia dumy, jak i jej braku. Emigranci podawali różne powody do dumy ze względu na swoją narodowość. Wśród nich znalazły się m.in.: polska tradycja i kultura, inteligencja rodaków, przywiązanie do wartości religijnych, bogata historia narodu oraz postawa reprezentowana przez wielu Polaków. Brak dumy był natomiast związany z negatywnymi postawami Polaków na emigracji, żalem z powodu konieczności wyjazdu z kraju czy stereotypami na temat Polaków.

Szacunek do kraju jest wyrazem patriotyzmu. Może on być okazywany $\mathrm{w}$ różnej formie. To zagadnienie omawiane było w kontekście pytania o stosunek do ojczyzny. Emigracja pozwala spojrzeć z dystansem na kraj swojego pochodzenia. Dokonywać jego oceny przez pryzmat nowych doświadczeń związanych z pobytem w społeczeństwie wielokulturowym. Spotykane w nowym środowisku odmienne poglądy, wartości, wzorce kulturowe, różne od tych, które są praktykowane w ojczyźnie, pozwalają migrantom przyjąć inną optykę. Może to wpływać na zmiany w dotychczasowym postrzeganiu kraju. Analizowane badania socjologiczne wyłoniły trzy grypy respondentów. Pierwsza zmieniła swój stosunek do kraju na pozytywny. Z perspektywy dostrzegają wiele pozytywnych aspektów życia i mieszkania w Polsce. Warto tu zauważyć, że pewna część respondentów podkreślała znaczenie religijnych i moralnych wartości charakterystycznych dla polskiego społeczeństwa ${ }^{24}$. Były one uważane za ważny element, który w społeczeństwie wielokulturowym i bardziej zliberalizowanym nie jest obecny w takiej skali. Emigracja pozwoliła niektórym osobom rozwinąć swoją religijność i duchowość, dla pewnej części migrantów bardzo ważną rolę odgrywają także tradycje religijne. Druga grupa migrantów nie zmieniła swojego stosunku do ojczyzny. Dominowały raczej pozytywne oceny swojego kraju. Ostania grupa to migranci, którzy zmienili swój stosunek do Polski na negatywny. Najczęstszym powodem takiej postawy było doświadczenie życia w kraju bardziej przychylnym realizacji planów rodzinno-zawodowych oraz

${ }_{23}$ M. Herrmann, Powody do dumy i wstydu bycia Polakiem, Komunikat z badań CBOS, BS/30/2010, Warszawa 2010, s. 3; B. Wciórka, Polacy o swoim zadowoleniu z życia, Komunikat z badań CBOS, BS/3/2010, s. $5-12$.

24 T. Adamczyk, Przemiany religijności migrantów, w: Doświadczenie rozwoju w życiu polskich migrantów..., s. 111-146. 
dostrzeżone z dystansu wady narodowe Polaków. Niektórzy z migrantów uważali także Polskę za kraj zacofany.

Ostanie analizowane zagadnienie dotyczyło sposobów podtrzymywania i rozwijania polskości w warunkach emigracyjnych. Wielu respondentów nie dostrzegało żadnych trudności związanych z podtrzymywaniem wartości patriotycznych. Bardzo ważną rolę pełnią tu różnego rodzaju instytucje wspomagające kultywowanie polskich wartości na emigracji. Można tu wymienić sobotnie polskie szkoły, biblioteki, domy polskie, a także polskie parafie. Wokół nich gromadzą się polscy migranci, podejmując różne zaangażowania na rzecz celów osobistych, ale również i społecznych, w tym patriotycznych. Z perspektywy indywidualno-rodzinnej polscy migranci podtrzymują i rozwijają polskość poprzez troskę o nauczanie dzieci języka polskiego, kultywowanie polskich tradycji i zwyczajów, w tym religijnych. Prezentują także przywiązanie do polskiej kuchni i potraw, o czym świadczą choćby liczne sklepy z rodzimymi produktami.

Postawy badanych migrantów w Wielkiej Brytanii wobec wartości patriotycznych są różnorodne. Badania jakościowe z wykorzystaniem indywidualnego wywiadu pogłębionego, w przeciwieństwie do jakościowych, nie opisują zjawisk za pomocą liczb i statystyk. Pomagają jednak w większym stopniu zrozumieć zmiany zachodzące w świadomości osób badanych. A te przebiegają w różnych kierunkach. Mogłoby się wydawać, że w dobie globalizacji w społeczeństwach wielokulturowych postawy patriotyczne będą zanikać. I takie zjawisko u pewnych osób badanych wystąpiło. Jest jednak również grupa osób, która w warunkach migracyjnych wartości patriotyczne odkrywa i rozwija. Pozostanie zawsze ważne pytanie, w jakim kierunku ten patriotyzm będzie ewoluował, gdyż badania socjologiczne wskazują, że jest to rzeczywistość o charakterze dynamicznym. Może być to więc patriotyzm egoistyczny i zamknięty, a może przyjąć postawę otwartą i wzbogacającą inne społeczności i kultury. Również ciekawym zagadnieniem badawczym może być porównanie postaw patriotycznych migrantów poakcesyjnych z postawami osób, które wyjechały do Wielkiej Brytanii przed wstąpieniem Polski do Unii Europejskiej. Długość pobytu na emigracji może mieć wpływ na postawy patriotyczne osób badanych i wyznawany przez nich system aksjologiczny. Problem ten wskazuje na potrzebę podejmowania kolejnych badań socjologicznych polskiej migracji, które uwzględniłby dodatkowe pytania i obszary badawcze.

\section{Bibliografia}

Adamczyk T., Przemiany religijności migrantów, w: Doświadczenie rozwoju w życiu polskich migrantów, Doświadczenie rozwoju w życiu polskich migrantów w Wielkiej Brytanii, Lublin 2018, s. 111-146. Arystoteles, Etyka nikomachejska, tłum. D. Gromska, Warszawa 1982.

Bartyzel J., Patriotyzm, w: Encyklopedia Katolicka, red. F. Gryglewicz, t. 15, Lublin 2011, s. 51-53. 
Boguszewski R., Głowacki A., Miedzy patriotyzmem a nacjonalizmem, Komunikat z badań CBOS 2016, nr 151.

Herling-Grudziński G., Życiński J., Pięć dialogów, Warszawa 1999.

Herrmann M., Powody do dumy i wstydu bycia Polakiem, Komunikat z badań CBOS, BS/30/2010, Warszawa 2010.

B. Wciórka, Polacy o swoim zadowoleniu z życia, Komunikat z badań CBOS, BS/3/2010.

Jasińska-Kania A., Dynamika zmian wartości Polaków na tle europejskim: EVS 1990-1999-2008, w: Polska po 20 latach wolności, red. M. Bucholc, S. Mandes, Warszawa 2011, s. 236-237.

Konferencja Episkopatu Polski, Chrześcijański kształt patriotyzmu, Tranów 2017.

Mariański J., Socjologia moralności, Lublin 2006.

Mariański J., Wartość/wartości, w: Leksykon socjologii moralności. Podstawy - teorie - badania perspektywy, red. J. Mariański, Kraków 2015, s. 877-882.

Mariański J., Patriotyzm Polaków w świetle badań socjologicznych, w: Wychowanie dla Niepodległej. W setna rocznicę odzyskania przez Polskę Niepodległości, red. L. Pawelski, Szczecinek 2018, s. 31-51.

Piwowarski W., Podstawowe wartości społeczeństwa polskiego, w: Liberalizm i katolicyzm dzisiaj, Lublin 10-12 XI 1992, Warszawa 1994, s. 1-10.

Piwowarski W., ABC katolickiej nauki społecznej. Cz. 1(Wprowadzenie, podstawy, kierunki), Pelplin 1993.

Plewko J., Doświadczenie rozwoju w życiu polskich migrantów w Wielkiej Brytanii, Lublin 2018, s. 89-110.

Szymczak W., Obszary społecznej partycypacji absencji, w: Doświadczenie rozwoju w życiu polskich migrantów w Wielkiej Brytanii, red. J. Plewko, W. Szymczak, T. Adamczyk, Lublin 2018, s. 171-194.

Wciórka B., Polacy o swoim zadowoleniu z życia, Komunikat z badań CBOS, BS/3/2010.

Wnuk-Lipiński E., Świat międzyepoki, «globalizacja», «demokracja», «państwo narodowe», Kraków 2014.

Żygulski K., Klasyfikacja i typologia wartości, w: Socjologia wychowania. Wybór tekstów, red. H. Mielicka, Kielce 2000, s. 221-224.

\section{Wartości patriotyczne w doświadczeniu polskich migrantów w Wielkiej Brytanii}

\section{Streszczenie}

Celem artykułu było ukazanie wartości patriotycznych w doświadczeniu polskich migrantów w Wielkiej Brytanii. Analizie został poddany materiał empiryczny zebrany metodą badań jakościowych przy pomocy techniki wywiadu pogłębionego. Materiał analizowany był z uwzględnieniem trzech zagadnień: poczucia dumy z bycia Polakiem, stosunku do ojczyzny oraz sposób podtrzymywania i rozwijania polskości. Socjologiczna analiza wskazała, że w społeczeństwach wielokulturowych zmiany w podejściu do wartości patriotycznych przebiegają w różnych kierunkach. U części migrantów wartości te zanikają, podczas gdy u innych są kultywowane, odkrywane i nawet rozwijane.

Słowa kluczowe: migracja, patriotyzm, ojczyzna, społeczeństwo wielokulturowe 


\title{
The values of patriotism in the experience of Polish migrants in Great Britain
}

\begin{abstract}
The aim of the article was to show patriotic values in the experience of Polish migrants in Great Britain. The empirical material collected using the qualitative research method using in-depth interview technique was analyzed. The material was analyzed taking into account three issues: a sense of pride in being a Pole, attitude towards the homeland and the ways of maintaining and developing Polishness. Sociological analysis has shown that in multicultural societies, changes in patriotic values occur in different directions. In some migrants, they disappear, while in others they are cultivated, discovered and even developed.
\end{abstract}

Key words: migration, patriotism, homeland, multicultural society 